\title{
2.6. Nowa rola placówek specjalnych
}

DOI: 10.47050/65591838.264-275

Anna Tomaszewska

W rozdziale omówiono nową rolę placówek specjalnych, jako Specjalistycznych Centrów Wspierania Edukacji Włączającej. Od wielu lat trwa debata na ten temat. Jest to ważna kwestia w dobie zmian w myśleniu o edukacji uczniów z niepełnosprawnościami oraz w kontekście ratyfikowanej w 2012 r. przez Polskę Konwencji o prawach osób niepełnosprawnych. Coraz więcej rodziców dla swoich dzieci wybiera szkoły ogólnodostępne, czyli tzw. edukację włączającą, jednak aby kształcenie było skuteczne, szkoła powinna otrzymać specjalistyczne wsparcie. W tym kontekście została przedstawiona nowa rola placówek specjalnych: cele, zadania, organizację oraz warunki konieczne do ich osiągnięcia i realizacji. W rozdziale wzięto pod uwagę doświadczenia placówek specjalnych, wnioski z debat oraz Rekomendacje Europejskiej Agencji do spraw Specjalnych Potrzeb i Edukacji Włączającej.

\section{Słowa kluczowe:}

\section{uczeń z niepełnosprawnościami}

włączenie społeczne

nowa rola placówek specjalnych 


\subsection{A new role of special schools}

DOI: $10.47050 / 65591838.264-275$

Anna Tomaszewska

The article discusses a new role of special schools as Specialist Support

Centers for Inclusive Education. The debate has been going on for many years. This is an important topic in the period of changes in thinking about the education of students with disabilities and in the context of the Convention on the Rights of Persons with Disabilities, ratified by Poland in 2012. More and more parents of pupils with disabilities choose mainstream schools, i.e. inclusive education. To make education effective, the school should get specialist support. A new role of special schools has been presented: goals, tasks, organization and conditions necessary to achieve and implement them. The article is based on experience of special schools, conclusions from debates and recommendations of the European Agency for Special Needs and Inclusive Education.

\section{Keywords:}

\section{student with disabilities}

\section{social inclusion}




\section{Stan obecny}

W Polsce od ponad dziesięciu lat trwa dyskusja dotycząca miejsca i warunków kształcenia uczniów ze specjalnymi potrzebami edukacyjnymi. Ministerstwo Edukacji Narodowej wielokrotnie podejmowało ten temat. Prowadzone były konsultacje i debaty społeczne. Różne gremia powoływały zespoły eksperckie w celu opracowania modelu nauczania osób z tej grupy. Intensyfikacja prac nastąpiła w 2012 r. po ratyfikowaniu przez Polskę Konwencji o prawach osób niepełnosprawnych, sporządzonej w Nowym Jorku w dniu 13 grudnia 2006 r.

Placówki kształcenia specjalnego, od przedszkoli poczynając, a na szkołach specjalnych i ośrodkach szkolno-wychowawczych kończąc, od wielu lat działały w celu integracji społecznej podopiecznych z niepełnosprawnościami (np. inicjowały kontakty z ich sprawnymi rówieśnikami). Realizacja tych zadań miała na celu m.in. włączenie społeczne.

Każda placówka specjalna w ramach swojej misji przygotowuje podopiecznych do osiągnięcia maksymalnej samodzielności, aby w przyszłości - zgodnie ze swoimi możliwościami psychofizycznymi - mogli prowadzić niezależne życie i odgrywać takie same role społeczne, jak ich pełnosprawni rówieśnicy. Ponadto, placówki zawodowe specjalne w procesie kształcenia wyposażają uczniów niepełnosprawnych w odpowiednie kompetencje i umiejętności umożliwiające podjęcie przez nich pracy na otwartym rynku pracy, w zakładzie pracy chronionej lub w ramach zatrudnienia wspomaganego.

W polskim systemie oświaty dzieci i młodzież otrzymują orzeczenie o potrzebie kształcenia specjalnego (wydawane przez publiczne poradnie psychologiczno-pedagogiczne) ze wskazaniem rodzaju niepełnosprawności lub sprzężenia. Edukacja może odbywać się w szkole zarówno ogólnodostępnej, jak i integracyjnej czy specjalnej. Decyzję o wyborze przedszkola czy szkoły dla swojego dziecka podejmują rodzice lub prawni opiekunowie. Wybór typu placówki wiąże się z konsekwencjami. Jeżeli jest to szkoła ogólnodostępna, najbliższa miejsca zamieszkania, to dziecko przebywa w swoim naturalnym środowisku, żyje w pobliżu rówieśników, z którymi się uczy w klasie. Jednak w rzeczywistości oświatowej zdarza się, że placówka nie jest przygotowana do podjęcia edukacji i rewalidacji ucznia z danym rodzajem niepełnosprawności. Przepisy prawa obligują ją do przyjęcia każdego dziecka mieszkającego w jej rejonie, niezależnie od stopnia i rodzaju potrzeb. 
W sytuacji, gdy jest to osoba z orzeczeniem o potrzebie kształcenia specjalnego, szkoła zobowiązana jest do zapewnienia odpowiednich warunków, specjalistycznych pomocy dydaktycznych wspomagających edukację, dostosowanych podręczników (np. w brajlu lub z powiększonym drukiem dla ucznia z dysfunkcją narządu wzroku) oraz realizację zaleceń zawartych w orzeczeniu. Jest to ogromne wyzwanie dla współczesnej szkoły - z jednej strony jest obowiązek narzucony przepisami prawa, z drugiej brak doświadczenia, specjalistów, wyposażenia i wsparcia. Obecnie szkoły ogólnodostępne albo kształcą swoich nauczycieli w zakresie pedagogiki specjalnej, najczęściej oligofrenopedagogiki, albo zatrudniają nauczyciela pedagoga specjalnego do prowadzenia zajęć rewalidacyjnych (dla jednego ucznia z orzeczeniem w wymiarze dwóch godzin tygodniowo). Dotyczy to szczególnie pedagogów specjalnych w zakresie niepełnosprawności sensorycznych. Jeżeli szkoła ogólnodostępna zatrudni nauczyciela z placówki specjalnej, to dysponuje on zapleczem zarówno w formie odpowiednich pomocy dydaktycznych, jak i możliwości konsultacji z kolegami. Jeżeli jednak nauczyciel pedagog specjalny jest zatrudniony tylko w kilku szkołach ogólnodostępnych, nie ma takich możliwości.

Zgodnie z obowiązującymi przepisami prawa, instytucjami wskazanymi do wspomagania szkół ogólnodostępnych są: placówki doskonalenia nauczycieli, poradnie psychologiczno-pedagogiczne i biblioteki pedagogiczne, które na to zadanie otrzymują subwencję oświatową. Jednak, jak pokazują praktyka i badania, nie mogą one sprostać wszystkim potrzebom.

W Rozporządzeniu Ministra Edukacji Narodowej z dnia 9 sierpnia 2017 r. w sprawie warunków organizowania kształcenia, wychowania i opieki dla dzieci i młodzieży niepełnosprawnych, niedostosowanych społecznie i zagrożonych niedostosowaniem społecznym, w par. 6.1.4, indywidualny program edukacyjno-terapeutyczny określa „w zależności od potrzeb, zakres współdziałania ze specjalnym ośrodkiem szkolno-wychowawczym".

W innym Rozporządzeniu Ministra Edukacji Narodowej z dnia 2 listopada 2015 r. w sprawie rodzajów i szczegółowych zasad działania placówek publicznych, warunków pobytu dzieci i młodzieży w tych placówkach oraz wysokości i zasad odpłatności wnoszonej przez rodziców za pobyt ich dzieci w tych placówkach, par. 47 wskazuje, że „specjalny ośrodek szkolno-wychowawczy współpracuje ze szkoła- 
mi ogólnodostępnymi w zakresie diagnozowania i rozwiązywania problemów dydaktyczno-wychowawczych uczniów niepełnosprawnych uczęszczających do tych szkół".

Niestety, w rozporządzeniach nie podano szczegółowych zadań ani sposobu finansowania wspomnianej współpracy. $Z$ doświadczenia wynika, że każdy specjalny ośrodek szkolno-wychowawczy wspiera szkoły ogólnodostępne w różnym zakresie w ramach dostępnych możliwości. Najczęściej nauczyciele specjaliści wykonują tę pracę "po koleżeńsku”, mając na uwadze przede wszystkim dobro niepełnosprawnego dziecka. Ośrodki organizują także seminaria i warsztaty, na które zapraszani są nauczyciele, rodzice oraz pracownicy poradni psychologiczno-pedagogicznych.

\section{Nowa rola placówek specjalnych}

W obecnej rzeczywistości polskiej oświaty, ze względu na to, że coraz więcej rodziców dzieci niepełnosprawnych wybiera dla swojego dziecka placówkę ogólnodostępną, zmieniają się rola i zadania przedszkoli, szkół i ośrodków specjalnych. Teraz są to dobrze wyposażone placówki specjalistyczne, zatrudniające profesjonalną kadrę, m.in. pedagogów specjalnych.

W krajach europejskich, niezależnie od tego, w jaki sposób realizowana jest edukacja uczniów z niepełnosprawnościami, rola placówek specjalnych uległa radykalnym zmianom. Ich nowym zadaniem jest wspieranie rodziców, uczniów z niepełnosprawnościami, nauczycieli w przedszkolach i szkołach ogólnodostępnych. W poszczególnych państwach europejskich zakres działań jest różny - od diagnostyki, przez szkolenie kadr, do bezpośredniego wsparcia uczniów. W zależności od polityki danego kraju, placówki specjalne zostały przekształcone w centra zasobów lub centra wsparcia, które - obok prowadzonej wcześniej edukacji - wspomagają szkoły ogólnodostępne.

W 2018 r. Ministerstwo Edukacji Narodowej zwróciło się do Europejskiej Agencji do spraw Specjalnych Potrzeb i Edukacji Włączającej o rekomendacje dotyczące wdrażania w Polsce edukacji włączającej wysokiej jakości, skierowanej do wszystkich uczniów. Agencja poddała analizie przepisy polskiego prawa oświatowego, odbyła debaty ze wszystkimi interesariuszami: niepełnosprawnymi uczniami, rodzicami, nauczycielami, dyrektorami, decydentami. Wynikiem jej pracy jest publikacja Wsparcie podnoszenia jakości edukacji włączającej 
w Polsce - rekomendacje i działania priorytetowe, w której sformułowano 16 rekomendacji i cztery działania priorytetowe. Rekomendacja nr 4 wskazuje, że: „Polityka edukacyjna powinna nakreślać nową rolę szkół specjalnych i innych placówek specjalistycznych, w ramach której udostępniają one placówkom ogólnodostępnym wiedzę fachową i specjalistyczne zasoby, zwiększając kompetencje kadry kierowniczej i personelu szkół w zakresie rozumienia i wspierania osób uczących się o zróżnicowanych potrzebach edukacyjnych. Oznacza to, że szkoły specjalne powinny wspierać placówki ogólnodostępne, działać jako baza dla multidyscyplinarnych zespołów wsparcia na poziomie lokalnym, co powinno zapewniać równy dostęp do usług w całym kraju".

Z kolei w art. 24 Konwencji o prawach osób niepełnosprawnych („Edukacja”), wskazuje się, że:

"1. Państwa Strony uznają prawo osób niepełnosprawnych do edukacji. W celu realizacji tego prawa bez dyskryminacji i na zasadach równych szans, Państwa Strony zapewnią włączający system kształcenia umożliwiający integrację na wszystkich poziomach edukacji i w kształceniu ustawicznym, zmierzający do:

(a) pełnego rozwoju potencjału oraz poczucia godności i własnej wartości, a także wzmocnienia poszanowania praw człowieka, podstawowych wolności i różnorodności ludzkiej,

(b) rozwijania przez osoby niepełnosprawne ich osobowości, talentów i kreatywności, a także zdolności umysłowych i fizycznych, przy pełnym wykorzystaniu ich możliwości,

(c) umożliwienia osobom niepełnosprawnym efektywnego udziału w wolnym społeczeństwie.

2. Realizując to prawo, Państwa Strony zapewnią, że:

(a) osoby niepełnosprawne nie będą wykluczane z powszechnego systemu edukacji ze względu na niepełnosprawność, a także, że dzieci niepełnosprawne nie będą wykluczane, ze względu na niepełnosprawność, z bezpłatnej i obowiązkowej nauki w szkole podstawowej lub z nauczania na poziomie średnim, (b) osoby niepełnosprawne będą korzystać z włączającego, bezpłatnego nauczania obowiązkowego wysokiej jakości, 
na poziomie podstawowym i średnim, na zasadzie równości z innymi osobami, w społecznościach, w których żyją,

(c) wprowadzane będą racjonalne usprawnienia, zgodnie z indywidualnymi potrzebami,

(d) osoby niepełnosprawne będą uzyskiwać niezbędne wsparcie, w ramach powszechnego systemu edukacji, celem ułatwienia ich skutecznej edukacji,

(e) stosowane będą skuteczne środki zindywidualizowanego wsparcia w środowisku, które maksymalizuje rozwój edukacyjny i społeczny, zgodnie z celem pełnego włączenia.

3. Państwa Strony umożliwią osobom niepełnosprawnym zdobycie umiejętności życiowych i społecznych, aby ułatwić im pełny i równy udział w edukacji i w życiu społeczności.

W tym celu Państwa Strony będą podejmować odpowiednie środki, w tym:

(a) ułatwianie nauki alfabetu Braille'a, alternatywnego pisma, wspomagających (augmentatywnych) i alternatywnych sposobów, środków i form komunikacji i orientacji oraz umiejętności poruszania się, a także ułatwianie wsparcia rówieśników i doradztwa,

(b) ułatwianie nauki języka migowego i popieranie tożsamości językowej społeczności osób głuchych,

(c) zapewnienie, że edukacja osób, w szczególności dzieci, które są niewidome, głuche lub głuchoniewidome będzie prowadzona w najodpowiedniejszych językach i przy pomocy sposobów i środków komunikacji najodpowiedniejszych dla jednostki, a także w środowisku, które maksymalizuje rozwój edukacyjny i społeczny [...]".

\section{Specjalistyczne Centra Wsparcia Edukacji Włączającej}

Wieloletnie doświadczenia placówek specjalnych w rozpoznawaniu potrzeb szkół ogólnodostępnych pokrywają się z wnioskami formułowanymi podczas debat i konsultacji społecznych, rekomendacjami Agencji oraz z zapisami Konwencji. Jednoznacznie wskazują na konieczność formalnego poszerzenia roli podmiotów tego typu. Podczas prac Zespołu powołanego przez Ministra Edukacji Narodowej w 2017 r. w celu opracowania modelu kształcenia uczniów ze specjalnymi potrzebami edukacyjnymi ustalono, że placówki specjalne powinny zostać 
przekształcone w Specjalistyczne Centra Wspierania Edukacji Włączającej. Miałyby one zachować dotychczasowe zadania związane z prowadzeniem szkół i (lub) oddziałów na każdym etapie edukacyjnym, a jeżeli zajdzie taka potrzeba, to również internatów. Rodzice w Polsce mają prawo wybrać do jakiego typu szkoły/przedszkola mają uczęszczać ich dzieci.

W raporcie Organizacja wsparcia dla edukacji włączającej z 2014 r. Europejska Agencja do spraw Specjalnych Potrzeb i Edukacji Włączającej podkreślała konieczność utrzymywania wysokiego profesjonalizmu kadry Centrów (s. 14, 25). Do spełnienia tego warunku niezbędne jest ciągłe nabywanie doświadczeń, dlatego w tych jednostkach powinna być prowadzona pełna edukacja, równolegle ze wspieraniem szkół ogólnodostępnych.

Zespół wskazał również możliwość elastycznego przechodzenia uczniów ze szkoły specjalnej do ogólnodostępnej lub odwrotnie. Może to być przydatne w sytuacji, gdy uczeń wymaga pracy w mniej licznym zespole, gdy jego niepełnosprawność i (lub) inne ograniczenia (np. emocjonalne) uniemożliwią mu stałe albo czasowe uczęszczanie do klasy ogólnodostępnej bądź wtedy, gdy w szkole specjalnej opanował niezbędne techniki i posługiwanie się specjalistycznymi pomocami.

Podczas międzynarodowej konferencji dotyczącej kształcenia uczniów z niepełnosprawnościami, która odbyła się w 2014 r. w Łodzi, przedstawiciele Portugalii i Norwegii, czyli państw, w których ok. 20 lat temu zlikwidowano szkoły specjalne, przestrzegali przed takim radykalnym krokiem. Twierdzili, że rolą placówek tego typu powinna być zarówno edukacja, jak i wspomaganie szkół ogólnodostępnych. Z ich doświadczeń wynika, że zawsze pojawią się takie dzieci, które wymagają szkoły specjalistycznej.

W publikacji Europejskiej Agencji do spraw Specjalnych Potrzeb Edukacyjnych i Edukacji Włączającej Organizacja wsparcia dla edukacji włączajq̨cej. Raport podsumowujq̨cy wskazano, że niekorzystne dla dzieci (uczniów) niepełnosprawnych jest tworzenie klas specjalnych w placówkach ogólnodostępnych (Europejska Agencja 2014, s. 9). Edukacja włączająca, zgodnie z rekomendacjami Agencji, powinna zapewniać wysoką jakość kształcenia. Ten cel można osiągnąć przez zaspokojenie potrzeb wszystkich uczniów, tym samym umożliwiając im aktywny udział w procesie nauczania. Przed szkołami ogólnodostępnymi zostało postawione trudne zadanie, jakim jest edukacja dla wszystkich, 
czyli nauczanie i wychowanie zróżnicowanych grup, w tym uczniów z różnymi niepełnosprawnościami.

Jak wspomniano na początku rozdziału, placówki specjalne wspierają szkoły ogólnodostępne od wielu lat i w wielu obszarach. Przed nimi, ale przede wszystkim przed Ministerstwem Edukacji Narodowej, stoi kolejne zadanie - nową rolę placówek specjalnych należy usankcjonować w systemie oświaty, zapewniając na ten cel odpowiednie środki finansowe.

Nowe struktury Centrum mogą być tworzone w placówkach specjalnych. Ponieważ jednak specjalne ośrodki szkolno-wychowawcze dla niepełnosprawnych sensorycznie nie obejmują swoim zasięgiem wszystkich województw, należałoby rozważyć powoływanie Centrów przy innych jednostkach.

\section{Podmiot ubiegający się o pełnienie funkcji Centrum powinien spełniać określone kryteria, m.in.:}

$\rightarrow$ Zatrudniać stały zespół doświadczonych specjalistów i pedagogów specjalnych, a także psychologa, nauczycieli przedmiotów z dodatkowymi kwalifikacjami w zakresie pedagogiki specjalnej, posiadających wiedzę na temat metod i narzędzi, specyficznych technik nauczania, rehabilitantów zajmujących się daną niepełnosprawnością, np. rehabilitanta wzroku, instruktora orientacji przestrzennej, nauczyciela alternatywnych metod komunikacji.

$\rightarrow$ Dysponować bazą lokalową i specjalistyczną (sprzęt i pomoce dydaktyczne), w celu utworzenia wypożyczalni. Bieżące doposażanie oraz wynagrodzenie dla jej pracowników powinno być zaplanowane w budżecie Centrum.

\section{Cele i zadania Specjalistycznego Centrum Wsparcia Edukacji Włączającej}

Centrum będzie oferowało specjalistyczne wsparcie ogólnodostępnym szkołom i przedszkolom, dzieciom z niepełnosprawnością, a także ich rodzinom.

Powinno wspomagać dzieci posiadające orzeczenie o potrzebie kształcenia specjalnego, uczące się w szkołach ogólnodostępnych. Odbywać się to może na wniosek rodzica, szkoły za zgodą rodziców, poradni psychologiczno-pedagogicznej lub innych instytucji (np. pomocy społecznej czy jednostek służby zdrowia). 


\section{Cele}

$\rightarrow$ zwiększenie dostępności do specjalistycznej pomocy rewalidacyjno-rehabilitacyjnej, doradztwa i konsultacji,

$\rightarrow$ stworzenie bezpośredniej możliwości korzystania przez uczniów, rodziców i nauczycieli z porad, konsultacji i informacji udzielanych przez specjalistów,

$\rightarrow$ zapewnienie systematycznej rewalidacji w celu skutecznego wspomagania procesu edukacji ucznia,

$\rightarrow$ wspieranie rodziców i nauczycieli w podnoszeniu ich kompetencji w zakresie wychowania i edukacji dziecka niepełnosprawnego,

$\rightarrow$ monitorowanie przebiegu edukacji i tranzycji na rynek pracy dziecka/ucznia - monitorowanie włączenia społecznego,

$\rightarrow$ ułatwienie dostępu do specjalistycznych pomocy i sprzętów technodydaktycznych.

\section{Zadania}

$\rightarrow$ koordynacja działań Centrum oraz szkoły ogólnodostępnej w zakresie wsparcia, edukacji i rehabilitacji ucznia z niepełnosprawnością i jego rodziny,

$\rightarrow$ dokonywanie wielospecjalistycznej oceny poziomu funkcjonowania dziecka/ucznia, współpraca ze szkołą przy opracowaniu indywidualnego programu edukacyjno-terapeutycznego,

$\rightarrow$ pomoc w zapewnieniu szkole specjalistycznych pomocy i sprzętów technodydaktycznych, zgodnie z potrzebami (np. wypożyczenie szkole stosownych narzędzi na czas edukacji dziecka lub ich przygotowanie),

$\rightarrow$ wnikliwa obserwacja dziecka w szkole, relacji uczeń - uczeń, uczeń - nauczyciel, wsparcie nauczyciela, w celu budowania prawidłowych relacji,

$\rightarrow$ prowadzenie specjalistycznych i rewalidacyjnych zajęć w zależności od potrzeb (częstotliwość zajęć ustala specjalista w porozumieniu z wychowawcą ucznia i jego rodzicami, opiekunami prawnymi),

$\rightarrow$ wspomaganie nauczycieli w zakresie organizacji miejsca dla ucznia, doboru metod i form pracy - bieżące konsultacje,

$\rightarrow$ prowadzenie szkoleń dla nauczycieli szkół ogólnodostępnych, dotyczących m.in. specyfiki funkcjonowania ucznia niepełnosprawnego; 
$\rightarrow$ pomoc w wyborze dalszego kierunku kształcenia lub typu szkoły oraz w przejściu (tranzycji) na kolejny etap edukacyjny lub na rynek pracy;

$\rightarrow$ podejmowanie działań edukacyjno-informacyjnych dla rodziców - wskazywanie potrzeby tworzenia dla nich grup wsparcia;

$\rightarrow$ współpraca z nauczycielami i rodziną przez cały okres edukacji ucznia;

$\rightarrow$ zapewnienie integracji ze środowiskiem rówieśników z tą samą niepełnosprawnością - budowanie tożsamości rówieśniczej;

$\rightarrow$ organizowanie wspólnych turnusów szkoleniowo-rehabilitacyjnych dla dzieci i rodziców oraz kolonii i obozów (zimowych, letnich) dla osób niepełnosprawnych i ich sprawnych rówieśników;

$\rightarrow$ okresowa ocena efektywności wsparcia udzielanego przez Centrum;

$\rightarrow$ gromadzenie danych dotyczących populacji dzieci/uczniów z niepełnosprawnością, w celu poznania potrzeb wsparcia (liczba uczniów, określenie niepełnosprawności);

$\rightarrow$ opracowywanie materiałów metodyczno-informacyjnych dla szkół, rodziców oraz innych resortów niż edukacyjny (pomoc społeczna, służba zdrowia).

\section{Organizacja i finansowanie}

Pedagodzy specjalni i inni eksperci będą nadal pracownikami placówek specjalnych, poszerzonych o strukturę Centrum. Jest to konieczne w celu zapewnienia bezpieczeństwa zatrudnienia oraz możliwości pracy w zespole multidyscyplinarnym. Pracownicy Centrum będą przenoszeni (np. na zasadach delegacji służbowej) do danej szkoły ogólnodostępnej w określonych dniach w tygodniu, w zależności od liczby uczniów z niepełnosprawnościami i ich potrzeb. Specjalistyczne zajęcia będą mogły być prowadzone w danej szkole ogólnodostępnej i (lub) w Centrum. Wielospecjalistyczna ocena funkcjonowania ucznia, w uzgodnieniu z jego rodzicami, może odbywać się w tej placówce ze względu na zespół specjalistów dokonujący oceny i konieczność korzystania ze specjalistycznego sprzętu. Efektywnym rozwiązaniem byłoby wyposażenie Centrum w samochody i busy ze specjalistycznym sprzętem i z pomocami. Umożliwiłoby to dokonanie oceny i dobranie pomocy bezpośrednio w szkole, do której uczęszcza dany uczeń i (lub) wypożyczenie tej placówce wymaganego sprzętu na czas jego edukacji. 


\section{Warunki osiągnięcia przedstawionych celów i realizacji zadań przez Centrum:}

$\rightarrow$ gotowość do zmiany u dyrektorów i nauczycieli szkół ogólnodostępnych oraz specjalistów z placówek specjalnych, a także decydentów na szczeblu centralnym i lokalnym,

$\rightarrow$ modyfikacja przepisów prawa oświatowego, uwzględnienie Specjalistycznych Centrów Wspierania Edukacji Włączającej jako placówek z podwójnymi zadaniami (edukacja i wspieranie szkół ogólnodostępnych),

$\rightarrow$ opracowanie zasad finansowania delegowanych nauczycieli oraz dodatków za pracę poza Centrum (wysokokwalifikowana kadra);

$\rightarrow$ przygotowanie mechanizmu finansowania zakupu sprzętu do wypożyczalni oraz ewentualnego zatrudnienia dodatkowego pracownika,

$\rightarrow$ opracowanie mechanizmu finansowania procesu przygotowania przez pracowników Centrum specjalistycznych pomocy, np. wydruk w piśmie brajla lub przygotowanie pomocy wypukłych - rysunków, map (środki na materiały i wynagrodzenie). 